\title{
Twenty-third Session of the Indian Science Congress
}

$\mathrm{T}$ HE twenty-third session of the Indian Science Congress was held at Indore, Central India, on January 2-8, 1936. More than 350 delegates from all over India met together under the presidency of Sir U. N. Brahmachari. The session was opened by $H$. $H$. the Maharajah of Indore, who, in inaugurating the meeting, said that the greatest problem of India is her poverty. It is the problem of increasing the yield of the soil and using India's vast mineral resources, which demands the most strenuous efforts of the scientific workers of India. He referred to the efforts that are being made at Indore, at the Institute of Plant Industry, to improve the quality of the crops. The Maharajah deplored the fact that while men of goodwill are straining every nerve of science in the cause of humanity, others are degrading the great achievements of that same science to the destruction of their fellow men. He fears that as the nineteenth century in Europe lost God in the laboratory, so they may lose all that is good in their ancient heritage owing to over-enthusiasm for the new.

Sir U. N. Brahmachari selected as the subject for his presidential address "The Role of Science in the Recent Progress of Medicine". His address is dealt with elsewhere in this issue (p. 330).

Dr. T. Royd's address to the Section of Mathematics and Physies dealt especially with three solar problems. He showed evidence for the essential identity of hydrogen dark markings and prominences; the former are projections on the sun's disk and the latter profiles at the limb of the same solar feature, the lengths of which along the sun's surface are of enormous dimensions compared to their heights and widths. Lengths exceeding 400,000 miles are comparatively frequently observed for this 'ribbon development' in the sun. The main difficulty of the radiation pressure theory of support of the chromosphere is to explain the presence of $\mathrm{H}, \mathrm{He}$ and $\mathrm{O}$, in addition to $\mathrm{Ca}+$ atoms. The role of radiation pressure, effective only on $\mathrm{Ca}^{+}$, is not negligible but is probably confined to the part of raising $\mathrm{Ca}+$ atoms only to that height where an unknown force operates to support the chromosphere and prominences, which are composed of all atoms present at that level. The results of spectrophotometry of Fraunhofer lines carried out at Kodaikanal Observatory have been interpreted to give the densities and pressures of electrons and of atoms of hydrogen and calcium in the lower part of the reversing layer.

In his presidential address to the Chemistry Section, Dr. P. C. Guha discussed recent developments in the chemistry of bicyclic terpenes. He described the salient features of bicyclic ring systems as a class-occurring naturally or otherwise-and their stereochemical aspect. The more important and recent advances in synthetic and degradative work on thujane, carane, pinane, camphane-fenchane, and the santane series of compounds were described. The results that have attended the experiments at the Indian Institute of Science were described, and the problems still awaiting solution pointed out. In addition to the many papers read before this Section, discussions were held on the "Utilisation of Molasses", and on "The Scope for Preparation of Fine Chemicals in India".

Mr. B. Rama Rao, in his presidential address to the Geology and Geography Section, dealt with various problems connected with the origin and classification of the crystalline schists of the Archean complex of Mysore. On the basis of the occurrence of two well-defined horizons of true sedimentary conglomerates, the Dharwar schists of southern India are tentatively classified into three divisions. The lowest amongst these forms an igneous complex composed mainly of basic lava flows, felsites, quartz porphyries, etc., and their crushed representatives. The other two divisions are formed of altered recognis. able sediments, with an admixture of various pro. portions of volcanic material. The Dharwar schists are fully developed in the northern parts of the State, and as they are traced southwards the upper division of this proposed classification disappears, and the lower is found considerably cut up and modified by the later intrusive granites. A progressive meta. morphism is indicated from north to south. A discus. sion was held in this Section on the classification of the Archæan rocks in India.

Dr. S. R. Bose, in his address to the Botany Section, dealt with the various aspects of Bengal Polyporacea, including their distribution, the con. ditions for their development in Bengal, the fossil records of Polyporacece, their morphology and system. atics, the anatomy as the basis of recent classification, their general structure, nutrition, cytology of reproduction and the chemical nature of fruit-body of Ganoderma lucidus, their biological peculiarities, their physiology, the nature of enzymes of some local Polypores in culture and their medicinal properties and other uses. Recently, Dr. Bose has reported that in specimens of Ganoderma lucidus and Ganoderma applanatus, the basidia are succeeded after the rains by hyphæ projecting direct from the trama and bear. ing secondary spores at their tips, which are quite indistinguishable from the ordinary basidiospores, and probably carry on spore discharge in the dry season. It is a matter for future investigation whether the basidia themselves are transformed into such tramal hyphæ-projections. Within this Section discussions were held on "The Myxophyceæ", "Saltation in Artificial Cultures of Fungi", "The Standardisation of the Vernacular Names of Indian Plants", "Chromosome Morphology and Polyploidy", and "The Importance of Anatomy and Taxonomy".

Dr. H. K. Mookherjee, presiding over the Zoology Section, discussed "The Development of the Vertebral Column and its bearing on the study of Organic Evolution". $\mathrm{He}$ showed that the vertebræ in all classes of vertebrates develop in a more or less similar way - a perichordial tube is converted into a bony ring apart from the notochordal sheaths which form the vertebral centrum. With regard to the formation of the centrum, the majority of the vertebrates con. form to the linear series, but there are exceptions which are explained as adaptations to changed conditions of life of the individuals concerned. Dr. Mookherjee discussed the components of the neural and lower arches in Urodela and referred to the two 


\section{Twenty-third Session of the Indian Science Congress}

$\mathrm{T}$ HE twenty-third session of the Indian Science Congress was held at Indore, Central India, on January 2-8, 1936. More than 350 delegates from all over India met together under the presidency of Sir U. N. Brahmachari. The session was opened by $H$. $H$. the Maharajah of Indore, who, in inaugurating the meeting, said that the greatest problem of India is her poverty. It is the problem of increasing the yield of the soil and using India's vast mineral resources, which demands the most strenuous efforts of the scientific workers of India. He referred to the efforts that are being made at Indore, at the Institute of Plant Industry, to improve the quality of the crops. The Maharajah deplored the fact that while men of goodwill are straining every nerve of science in the cause of humanity, others are degrading the great achievements of that same science to the destruction of their fellow men. He fears that as the nineteenth century in Europe lost God in the laboratory, so they may lose all that is good in their ancient heritage owing to over-enthusiasm for the new.

Sir U. N. Brahmachari selected as the subject for his presidential address "The Role of Science in the Recent Progress of Medicine". His address is dealt with elsewhere in this issue (p. 330).

Dr. T. Royd's address to the Section of Mathematics and Physies dealt especially with three solar problems. He showed evidence for the essential identity of hydrogen dark markings and prominences; the former are projections on the sun's disk and the latter profiles at the limb of the same solar feature, the lengths of which along the sun's surface are of enormous dimensions compared to their heights and widths. Lengths exceeding 400,000 miles are comparatively frequently observed for this 'ribbon development' in the sun. The main difficulty of the radiation pressure theory of support of the chromosphere is to explain the presence of $\mathrm{H}, \mathrm{He}$ and $\mathrm{O}$, in addition to $\mathrm{Ca}+$ atoms. The role of radiation pressure, effective only on $\mathrm{Ca}^{+}$, is not negligible but is probably confined to the part of raising $\mathrm{Ca}+$ atoms only to that height where an unknown force operates to support the chromosphere and prominences, which are composed of all atoms present at that level. The results of spectrophotometry of Fraunhofer lines carried out at Kodaikanal Observatory have been interpreted to give the densities and pressures of electrons and of atoms of hydrogen and calcium in the lower part of the reversing layer.

In his presidential address to the Chemistry Section, Dr. P. C. Guha discussed recent developments in the chemistry of bicyclic terpenes. He described the salient features of bicyclic ring systems as a class-occurring naturally or otherwise-and their stereochemical aspect. The more important and recent advances in synthetic and degradative work on thujane, carane, pinane, camphane-fenchane, and the santane series of compounds were described. The results that have attended the experiments at the Indian Institute of Science were described, and the problems still awaiting solution pointed out. In addition to the many papers read before this Section, discussions were held on the "Utilisation of Molasses", and on "The Scope for Preparation of Fine Chemicals in India".

Mr. B. Rama Rao, in his presidential address to the Geology and Geography Section, dealt with various problems connected with the origin and classification of the crystalline schists of the Archean complex of Mysore. On the basis of the occurrence of two well-defined horizons of true sedimentary conglomerates, the Dharwar schists of southern India are tentatively classified into three divisions. The lowest amongst these forms an igneous complex composed mainly of basic lava flows, felsites, quartz porphyries, etc., and their crushed representatives. The other two divisions are formed of altered recognis. able sediments, with an admixture of various pro. portions of volcanic material. The Dharwar schists are fully developed in the northern parts of the State, and as they are traced southwards the upper division of this proposed classification disappears, and the lower is found considerably cut up and modified by the later intrusive granites. A progressive meta. morphism is indicated from north to south. A discus. sion was held in this Section on the classification of the Archæan rocks in India.

Dr. S. R. Bose, in his address to the Botany Section, dealt with the various aspects of Bengal Polyporacea, including their distribution, the con. ditions for their development in Bengal, the fossil records of Polyporacece, their morphology and system. atics, the anatomy as the basis of recent classification, their general structure, nutrition, cytology of reproduction and the chemical nature of fruit-body of Ganoderma lucidus, their biological peculiarities, their physiology, the nature of enzymes of some local Polypores in culture and their medicinal properties and other uses. Recently, Dr. Bose has reported that in specimens of Ganoderma lucidus and Ganoderma applanatus, the basidia are succeeded after the rains by hyphæ projecting direct from the trama and bear. ing secondary spores at their tips, which are quite indistinguishable from the ordinary basidiospores, and probably carry on spore discharge in the dry season. It is a matter for future investigation whether the basidia themselves are transformed into such tramal hyphæ-projections. Within this Section discussions were held on "The Myxophyceæ", "Saltation in Artificial Cultures of Fungi", "The Standardisation of the Vernacular Names of Indian Plants", "Chromosome Morphology and Polyploidy", and "The Importance of Anatomy and Taxonomy".

Dr. H. K. Mookherjee, presiding over the Zoology Section, discussed "The Development of the Vertebral Column and its bearing on the study of Organic Evolution". $\mathrm{He}$ showed that the vertebræ in all classes of vertebrates develop in a more or less similar way - a perichordial tube is converted into a bony ring apart from the notochordal sheaths which form the vertebral centrum. With regard to the formation of the centrum, the majority of the vertebrates con. form to the linear series, but there are exceptions which are explained as adaptations to changed conditions of life of the individuals concerned. Dr. Mookherjee discussed the components of the neural and lower arches in Urodela and referred to the two 
additional membrane bone arches he has discovered, both in connexion with the neural arch and the lower arch. The presence of the transverse processes in the vertebrate series from Amphibia to Mammalia is recorded and their modification in certain forms, such as Xenopus, Bombinator, Gecko and Naja, is described. Successive vertebræ are yoked together in the embryonic stage by longitudinal processes that are cut into two halves by a strand of migratory connective tissue, so as to produce the articular facets. The migratory connective tissue cells divide the originally continuous perichordal tubes into vertebral segments, and the direction followed by these cells determines whether the centrum is to be of procclous, opisthocœlous or amphicœlous type. The course followed by the migratory cells is probably influenced by the movement of the embryos.

"The Problems of the Racial Composition of the Indian Peoples" was discussed by Mr. H. C. Chakladar in his address to the Anthropology Section. The racial classification of the Indian peoples has up to date proceeded on very scanty anthropometric data and hence been quite unsatisfactory. Risley's classification of them, based upon inadequate material, into seven racial types has rightly been rejected by anthropologists. Dr. Hutton's classification in the last Census Report of India has also been questioned in various respects. The Veddaic type in India he calls Proto-Australoid, although craniological evidence makes the theory of a common racial stock for the jungle tribes of the Deccan and the aborigines of Australia quite untenable. The theory of their migration into India from Asia Minor is also disproved by the great difference in nasal index between the ancient Mesopotamian and Indian skulls. Regarding the theory of the introduction of Aryan culture into India by dolichocephalic Proto-Nordics, the Aryan-speaking brachycephals had certainly entered India earlier than this type, and Vedic culture probably originated with them, or with a people in whom the two types were already mixed before they entered India. It is also necessary to revise the theories about the racial history of the Dravidians, who are found to include round-heads with Alpine, and longheads with Mediterranean, affinities. But these two types are not peculiar to the Dravidianspeaking people alone; intensive anthropometric work among the Bengalis shows the presence of these two types among them, and their presence is indicated in other parts of India too.

In his presidential address to the Section of Agriculture, Mr. A. K. Yagna Narayana Aiyer discussed some aspects of scientific research as applied to the improvement of Indian agriculture during the past twenty-five years, with particular reference to Mysore State. Improvements in agricultural implements, in manures, in varieties of crops, and in remedial measures against plant diseases, were described. Special reference was made to the recent development of the sugar industry in Mysore State. Its rapid development has been due to the Krishnarajasagara dam across the Cauvery, which is designed to bring under irrigation something like 150,000 acres of dry land. Already, in three years, 11,000 acres have been intensely cultivated, and associated industries for the utilisation of by-products have rapidly grown up. Another instance of the co-operation between agriculture and industry is the cultivation of American tobacco in the Guntur district, an industry that has expanded to such an extent that it is able to export cigarette tobacco to
Great Britain. Finally, particular emphasis was laid upon the necessity for improved agricultural marketing. A joint discussion was held with the Medical Section on "The Making of Humus and its Application".

Colonel H. E. Shortt, in his presidential address to the Section of Medical and Veterinary Research, discussed the problem of immunity in protozoal disease. The fact that most diseases due to protozoa appear to leave little or no immunity following cure has led many observers in the past to consider that the immunity responses to protozoal infections must be different from those called forth by bacterial infections. A study, however, of infections due to trypanosomes, pathogenic and non-pathogenic, malarial parasites, avian and mammalian, Leishmania, visceral and dermal, and the various species of Babesia clearly brings out three points. The immunity mechanisms are essentially the same whether the invader be bacterium, protozoan, or any other foreign substance. The immunity is intensely specific, even to the extent of being specific to strains within a single species. In most cases the immunity is dependent on the continued presence in the host of the specific organism.

In his address to the new Section of Physiology, Prof. W. Burridge discussed some future lines of advance in physiology and medicine. The behaviour of rhythmical structures when stimulated and the laws governing their stimulation are additions to physiological knowledge. Living organs when stimulated obey these laws and behave like rhythmical structures. They therefore possess inherent rhythm. This new knowledge further demonstrates that the electrical excitation of muscle and nerve is a laboratory artefact and not the natural stimulation it has been presumed to be. Physiologists, however, have built their science on this and other false presumptions. The time is ripe for discarding the pseudoscience built thereon, and to rebuild on the surer foundations of the new and easily verifiable facts. A joint discussion was held with the Medical Section on "The Problem of Nutrition in India".

Mr. J. M. Sen, presiding over the Psychology Section, took as the subject of his address "Measurement in Education". In all problems of education, two things are of fundamental importance: one is the child who is to be educated with his inherited traits, and the other the environment in which he grows up. But both are variables; no one can fully predict what a child is going to be, nor is it impossible to change the environment to a certain extent. Education is therefore a function of two real variables. A detailed study of the intelligence quotients and intelligence deviations of children shows that educability can be transmitted, but the results of education cannot be transmitted. On account of individual differences it is not possible to have a homogeneous grouping for class purpose. It is much better to have an 'ability grouping' rather than 'achievement grouping' for the purpose of class teaching. The general nature of a pupil's abilities may be registered by a single point in a tridimensional record or graph, the co-ordinates of the point being the values of the three independent factors $G$ (general intelligence), $W$ (persistence of motives), and $C$ (originality or cleverness) described by Spearman, Webb and Maxwell Garnett respectively. All three factors cannot be identical even in two cases, not to speak of three or more cases. Hence it is necessary to develop the potentialities of a pupil during his school age by 
creating for him an atmosphere of study and character congenial to all and not inimical to the best interests of the society as a whole.

During the session, the first annual meeting of the National Institute of Sciences of India was held under the presidency of Sir Lewis Fermor, who took as the subject of his address "Methods used in the Correlation of Archaean Rocks". During the meeting it was announced that Prof. N. Bohr, Prof. A. Einstein, Sir Thomas Holland, Sir Frederick Gowland Hopkins, Sir Guy Marshall, Lord Rutherford of Nelson and Sir Charles Sherrington had become the first honorary fellows of the Institute.

At the annual meeting of the General Committee of the Indian Science Co gress Association, it was unanimously resolved to celebrate the silver jubileo of the Science Congres in January 1938 by inviting a deputation of scientific workers from the British Association and elsewhere to join in the meeting. Should this materialise, it is likely to be a landmark in the progress of science in India, and it is to be hoped that adequate financial support for this venture will be fortheoming.
W. D. WEST.

\section{Science and Progress in Medicine}

$\mathrm{I}^{\mathrm{N}}$ his presidential address to the twenty-third Indian Science Congress, held in Indore on January 2-8, Sir U. N. Brahmachari discussed the role of science in the recent progress of medicine. $\mathrm{He}$ said that no apology was needed for his choice of subject, since health is the foundation of all happiness; moreover, it is customary at the annual meetings for the president to refer to the recent advances in science, and as the progress as well as the future achievements of medicine depend to a great extent upon the help that she has had and may yet get from the other sciences, it was only suitable for him to give a review of the important contributions made by some of these other sciences in recent times towards the advancement of medicine. $\mathrm{He}$ also referred to some recent facts which may be of medical interest in the future.

The president then reviewed briefly recent contributions to knowledge made by the sciences of biochemistry and chemistry, physiology, physics and mathematics, psychology and genetics. $\mathrm{He}$ emphasised the importance of diet and referred to the statement that man's place in future history will depend in no small degree on the food he eats. He pointed out the gaps in our present knowledge of nutrition, such as our ignorance of what is the optimum intake of protein or fat. The minimum animal protein required for human consumption is an interesting subject for research, and the future may show that it may be influenced by climatic conditions, as well as by its relationship to other constituents of the diet. He suggested that certain obscure diseases of India should be investigated from the point of view of a mineral deficiency being the cause. He also referred to the work carried out by Tilak and his assistants on balanced diets for Indians : the dietary worked out by them includes, with the staple food grains in common use, soya beans, dried skimmed milk, rice polishings, fresh ground-nut cake and a preparation of sprouted seeds. Such dietaries may help to solve the problem of obtaining a reasonably good diet at a price the people can afford. Perhaps the science of nutrition will one day form part of the Department of Preventive Medicine of the State.

In the field of chemotherapy, Sir U. N. Brahmachari referred to his own and his colleagues' work on various aminoquinoline derivatives as antimalarial agents : they have found that the introduction of a hydroxy group increases the toxic action of the compounds on Paramecia, whilst that of a methoxy group abolishes their toxicity. He also mentioned some work on the hypnotic properties of extracts from the root of Rauwolfia Serpentina, and then briefly reviewed his investigations on the treatment of kala-azar with preparations of antimony, culminating in the discovery of urea stibamine, which to-day is pre-eminent in the treatment of this disease. Turning to the future, he envisaged the possibility that the isotopes of elements may play an important part in the maintenance of health and that they may vary in disease.

The contribution of physies to medical science has been partly in the domain of diagnosis and partly in that of treatment. For diagnosis come such instruments as the electro-card:ograph, the oscillograph, the ultra-violet microscope, the infra-red camera, the $\mathrm{X}$-ray tube and the spectrograph : for treatment, radium, light and electrotherapy and the $\mathrm{X}$-ray also, the latter having been used as well for crystal analysis. It is possible that $\mathrm{X}$-ray analysis may solve the problem of the order of the unit groups in a protein chain and so ultimately the structure of living matter. In fact, when we survey the immense development in the use of light waves, visible, ultrs. violet, X-ray and others in the investigation of structures and the treatment of disease, with their future potentialities, it may be said without conceit -truly we are beginning to see through a glass less darkly.

In his concluding remarks, Sir U. N. Brahmachari said that it is clear that the various sciences can be of great service to medicine, and that some of them have contributed very substantially to the relief of human suffering from disease. The science of medicine, which was once mostly limited to the study of disease, is now concerning herself with the study of health, by the increasing knowledge of nutrition, environment and eugenies. Life is adapting itself to many varied conditions and to considerable ex. tremes of environment. The capacity of man for adaptation has been achieved and can be maintained only by the possession of an almost changeless and constant medium, the blood, which acts as the direct environment of his most valuable possession, namely, the brain: surely the level at which the essential blood constituents are maintained may be called the constant of and for man, as fixed as other physical constants. Whether mankind advance or regress in the future, medicine and civilisation will advance and regress together for all time. 